\title{
Secret organisations and their overt politics
}

In line with the concept of politics developed by ancient Greeks, the political sphere is identified with transparency and overtness, yet it has always been hiding secret actions, conspiracies and collusions. This is particularly true of political power because, as Elias Canetti remarks, 'secrecy lies at the very core of power.' ${ }^{\text {'Secret }}$ associations created within this sphere sought either to overthrow, change or take over power, or to strengthen it, by provoking its political opponents to disclose. Only the emergence of the modern model of the state, along with the rationalisation of its structures, enabled these secret equivalents of authority to transform into organisations, i.e. institutions alternative to official organisations, established by law and having specific powers.

This meant that secret organisations were created in opposition to the overt administrative and political structures of the state in order to eradicate them or take them over. This involved both defining their new functions and redefining their aspirations. Their goals increasingly became ideological, and their primary function was to participate in power by influencing overt politics, shaping political decisions and changing the system, etc. In this sense,

Barbara A. Markiewicz - Professor, PhD with Habilitation (a post-doctoral degree), is a graduate of Polish Studies (Jagiellonian University) and Philosophy (The University of Warsaw). Her main subjects of interest are the history of philosophy, the philosophy of politics and the didactics of philosophy. She is the author of nearly three hundred academic papers.

1 E. Canetti, Crowds and Power, translated by C. Stewart, New York: Continuum, p. 290. 
the political activities of secret organisations were essentially transparent by nature (i.e. public). Some of these secret societies and associations finally became legal (i.e. overt) organisations, e.g. parties. Others remained, and continue to remain, secret. Rather than talking about actual organisations, I will discuss the process whereby these secret, underground structures turn into organisations that influence the sphere of overt politics. I will try to show that this is a specific kind of game between what is explicit and public and what is concealed and secret. This game is constantly present in political activities, although we seldom realise it.

The main focus of my interest is the rules of this game which have been worked out in the sphere of politics. It is worth recalling, however, that when transposed into the opposition between truth and falsehood, the problem of the relationship between what is overt (light) and what is concealed (darkness) has been intriguing to philosophers from the very beginning. Parmenides begins his philosophical poem from the separation of these orders. Plato develops his theory of ideas based on this opposition. It is later developed on the level of ontology as a dialectic of being and non-being by philosophers such as Georg Wilhelm Friedrich Hegel and Martin Heidegger. All these concepts show that concealedness (closedness, darkness) and unconcealedness (openedness, light) are complementary. If we agree with ancient thinkers that truth is aletheia (unconcealedness), then concealedness, a mystery, is synonymous with pseudos, i.e. falsehood. This does not mean, however, that the content of the mystery cannot be true. This only means that truth exists in secrecy and that this state of existence takes away its value of truth in the sense that what is widely available also becomes verifiable. Rarely, however, is it pointed out that it is concealedness (closedness) that acts as arche in relation to unconcealedness - it is what comes first and what determines the form of what is disclosed and the manner in which it is disclosed. This is pointed out by Heidegger, who 
reaches back to the origins of philosophy and reflects on the ancient concept of truth understood as aletheia:

The concealment of beings as a whole, un-truth proper [Gr. pseudos

- BM], is older than every openedness [truth, Gr. aletheia - BM] of this or that being. [...] What conserves letting-be in this relatedness to concealing? Nothing less than the concealing of what is concealed as a whole, of beings as such, i.e., the mystery. ${ }^{2}$

In other words: what is concealed is a precondition for what is transparent, i.e. it can reveal itself from the concealed, secret and, what is more, it stores the memory of what is concealed as the most important human mystery. Since I am primarily interested in the philosophy of politics, I will point to the political aspect of these issues without discussing them further on the level of pure ontology and metaphysics. Hannah Arendt sees the Greek polis, a political community, primarily as an opposition to oikos, i.e. a house. In principle, this is an opposition between openedness, transparency, the public nature of polis and that what is closed, dark and private, such as a house. When discussing the phenomenology of the political world, Klaus Held states that the opening up of the political world has created its meaning by making it a response to the secrecy of the household. ${ }^{3}$

On the basis of Aristotle's Politics, it can also be said that in the theoretical order, which explains the meaning of the political sphere, it is the sphere of transparency that determines the nature of what is concealed in politics. However, in the empirical order - i.e. in research based on what is individual, detailed - the political sphere (what is common, public, open) is secondary to the sphere of what is concealed. It stems and develops from the level of oikos - houses that make up incomplete communities, such as municipalities.

\footnotetext{
2 M. Heidegger, Pathmarks, translated by W. McNeil, Cambridge: Cambridge University Press, 1998, p. 148.

${ }^{3}$ K. Held, Towards a Phenomenology of the Political World. The Oxford Handbook of Contemporary Phenomenology, edited by D. Zahavi, Oxford: Oxford University Press, 2012.
} 
The relationship between what is concealed, undisclosed and what is disclosed or made transparent from this space has yet another interesting aspect. A mystery, a secret and that what is concealed cannot be readily available. The special way in which a mystery functions is already reflected in the way we think about it. One can be let into a secret and take part in it. Just as in a legal sense, participation in a secret or mystery entails certain privileges (initiation into a secret) and obligations, the most important of which is to keep the secret. Someone who has been let into a mystery or a secret becomes its co-owner, and the secret itself becomes the property of those who have learnt it. A secret, however, is a special kind of property, especially if someone is its only possessor. It is often felt to be a burden and sometimes there is a thirst or even a necessity to need to share it with someone.

Sharing a mystery or a secret, however, entails a process of its discovery, disclosure. As Jacques Derrida shows in his How to Avoid Speaking: Denials ${ }^{4}$, this process takes the form of a special game of appearances and simulations. According to Derrida, a mystery or a secret is a paradoxical structure, which in essence assumes concealment that demands disclosure. As Derrida writes:

There is a secret of denial [dénégation] and a denial [dénégation] of the secret. The secret as such, as secret, separates and already institutes a negativity; it is a negation that denies itself. It de-negates itself... This denial [dénégation] does not happen [to the secret] by accident; it is essential and originary.... The enigma... is the sharing of the secret, and not only shared to my partner in the society but the secret shared within itself, its 'own' partition, which divides the essence of a secret

\footnotetext{
${ }_{4}$ Cf. J. Derrida, How to Avoid Speaking: Denials, in: idem, Languages of the Unsayable, translated by K. Frieden, New York: Columbia University Press, 1989. According to Agata Bielik-Robson, who has analysed the text, a secret is one of Derrida's core motifs and his teaching about a secret 'oscillates around what is supposedly concealed and confidential so significantly and intensely that it eventually reveals everything, though never in a straightforward manner'. A. Bielik-Robson, Gra w trzy ognie. Derridiańska trylogia o duchu, http://myslec.pwn.pl/Download/Gra-w-trzy-ognie.-Derridianska-trylogia-o-duchu-AgataBielik-Robson, p. 3 (accessed on July 2017).
} 
that cannot even appear to one alone except in starting to be lost, to divulge itself, hence to dissimulate itself, as secret, in showing itself: dissimulating its dissimulation. There is no secret as such; I deny it. ${ }^{5}$

Silence is, of course, the best way to protect a mystery or a secret, the concealed. Having a secret requires us to leave the sphere of logos in the sense of rationality, law and language. Although a secret can be revealed in many ways (e.g. through careless behaviour or contact with the wrong person), the most common is garrulity. Max Horkheimer and Theodor W. Adorno offer an interesting approach to this issue in their Dialectic of Enlightenment when describing the adventures of Odysseus with the Cyclops. ${ }^{6}$ Satisfied with his own cunningness and the success of his secret plan whereby the voracious Cyclops was blinded, the usually rational Odysseus revealed that he was the author of the plan. In their comment, Horkheimer and Adorno notice that " $b] y$ talking too much he gives away the principle of violence and injustice underlying discourse and provokes in the feared adversary the very action he fears'. ${ }^{7}$

Therefore, silence as a way to defend a secret is conditioned by concern and often by fear of consequences that may arise from participation in something that is beyond the law or the accepted ethical order. Derrida notes, however, that a secret in which many people participate tends to be shared and thus transferred to the sphere of transparency. This is done through what he refers to as a game of appearances and simulations which consists of making suggestions, demonstrations and allusions or in expressing symptoms.

The Greek word symptoma, symptomatos also means a coincidence, an accident. When used in reference to a disease, the word symptom can be understood to be a coincidental

5 J. Derrida, How to Avoid..., p. 25.

6 M. Horkheimer, T.W. Adorno, Dialectic of Enlightenment, translated by E. Jephcott, Stanford: Stanford University Press, 2002.

7 Ibidem, p. 54. 
combination of internal processes and the external state of the body that signals a certain medical condition. This does not mean, however, that phenomena perceived (e.g. rash, fever, unconsciousness) are unambiguously linked to a certain medical condition. The same applies to a mystery. It functions in the public sphere as a rumour, suggestion or conjecture as long as it is not fully disclosed. This also applies to secret organisations. They are, therefore, the main subjects of conspiracy theories. Their existence, structure and, sometimes, their goals remain basically secret. However, many members of such organisations share the secret of their existence and therefore, on the basis of expression, various types of symptom-like events occur (e.g. repeated meetings of the same persons, specific behaviour, gestures, glances or statements). This makes it possible to recognise, 'track' and identify these organisations, although the identification may be false or illusory due to the specificity of the symptoms.

For example, one of the most famous secret organisations involved in the political area, i.e. Freemasonry, was identified in such a symptomatic manner. Therefore, I use the example of this organisation to concretise the game between the secret existence of politically motivated associations and their influence on overt politics. Especially as the case of Freemasonry also confirms the above-mentioned thesis that what is concealed takes primacy over that what is disclosed in the area of politics. According to this principle, the secret activity of Freemasonry became a catalyst for processes that helped to create a 'third state' in France. According to Reinhart Koselleck, this was connected with a new content of the mystery, '[it] was the mystery of a third power, a power living by its self-made law; as in Locke's Essay it had stepped as "Law of private censure" beside the Divine Law and the Civil Law."

When investigating this issue in the context of the emergence of the bourgeois world, Koselleck recognised it as one of the most

\footnotetext{
8 R. Koselleck, Critique and Crisis: Enlightenment and the Pathogenesis of Modern Society, Cambridge, Massachusetts: MIT Press, 1988, p. 72.
} 
important signs of pathogenesis of modernity. Marcin Moskalewicz and Jakub Duraj, the translators and authors of the Introduction to the Polish version of Koselleck's book, state that '[p]athogenesis explains the emergence of a historically and statistically abnormal situation in the social tissue, which turns into a norm over time (emphasis by BM)'. ${ }^{9}$

It can be assumed that the emergence of the bourgeois world, which was associated with the activity of Freemasonry in the general political game discussed here - to say nothing of the dialectic of darkness and light, of the concealed and the disclosed - contributed to the creation of a new political paradigm.

The history of Freemasonry, as well as its structure, programme and significance, has long been disclosed and well examined, including from the philosophical perspective. This does not mean, however, that the organisation now operates in an utterly overt and public way, since it continues to be closed and elitist. However, because its genesis has clearly defined its structure and political objectives, it is important to recall the main facts.

According to textbooks, encyclopaedias and scientific papers, the origins of Freemasonry as formal, secret organisation go back to the $14^{\text {th }}$ century. But at the beginning it was established as public corporations of builders who constructed Gothic cathedrals, monastic complexes and castles in England and Scotland. In 1376, members of such corporations began to be called freemasons. Structurally, these organisations were loose teams of bricklayers from a particular area. Each of these teams, as Ludwik Hass points out, gathered in closed builders' premises, commonly referred to as lodges, whose hierarchy was a reflection of the medieval hierarchical structure of guilds. Each lodge was headed by a Master, who was elected for a period of time by members of the lodge. Hass emphasises that such an organisation 'was not

9 R. Koselleck, Krytyka i kryzys. Studium patogenezy świata mieszczańskiego, translated by J. Duraj, M. Moskalewicz, Warszawa: Res Publica Nowa, 2015, p. 10. 
only a professional association, but also a moral institution, and something like a church fraternity and a mutual-aid society. ${ }^{10}$

In the Middle Ages, such associations existed throughout Europe. Their members were:

[...] not ordinary craftsmen but the professional elite of builders: bricklayers, i.e. - using the present -day terminology - minor and major building contractors, engineers-designers and engineers-contractors, as well as stonemasons-artists, who were the most numerous in this group, and novices who were learning these skills. ${ }^{11}$

The unique position of these organisations and their way of functioning, which was closely linked to the need for secrecy, was primarily the result of the specialised knowledge and special skills possessed by their members. For the people of the time, the way in which great buildings, and Gothic cathedrals in particular, were constructed was beyond human measure, incomprehensible, and therefore could not be reduced to technical knowledge or the ability to use complicated tools. This opinion was supported by members of masonry corporations. For this reason, the knowledge they possessed began to resemble esoteric knowledge, and its acquisition was a kind of initiation. Its principles were linked to religious and mystical formulas, and a ban on writing them down was introduced. Novices were given this knowledge in the form of sacred symbols and allegories for mnemotechnical purposes.

However, it was not only knowledge and the way in which it was passed on that determined the specific nature of Freemasonry. Unlike many other local fraternities and corporations in medieval Europe, members of Freemasonry often changed their whereabouts. As a result, masonic associations remained independent of local authorities and had no central power themselves. Their members wandered throughout Europe, wherever they were invited to for construction purposes. They met and worked together for a long

10 L. Hass, Sekta farmazonii warszawskiej. Pierwsze stulecie wolnomularstwa $w$ Warszawie (1721-1821), Warszawa: Państwowy Instytut Wydawniczy, 1980, p. 32 (my translation).

${ }^{11}$ Ibidem, p. 30. 
time on such occasions, which created strong transethnic and transnational solidarity between them. According to Hass, this mobility also significantly influenced the ideological nature of Freemasonry as it involved breaking geographical and even social barriers. Consequently:

Bricklayers became accustomed to a variety of working conditions, lifestyles and ways of thinking. They therefore created the idea of anthropological equality, regardless of biological variations within the species, and developed at least an understanding for different behaviours of the human species - a kind of worldview tolerance - and a restrained attitude to the extremes of all orthodoxy. ${ }^{12}$

It can, therefore, be said that Masonic associations formed during the feudal period retained the structural features of the old society, which determined their cohesion and their ability to survive in the structures of the new state. The external features and structures of former corporations were preserved, although their goals fundamentally changed. The combination of political and religious elements led to the formation of organisational order outside the structures of the state and church. Emphasis on secrecy made Freemasonry different from $17^{\text {th }}$ century religious sects, although their members attached great importance to cults and rites, etc. Most importantly, the content of their 'mystery' changed substantially. It did not concern the previously well-guarded professional knowledge of building techniques, but new knowledge which was contained and transmitted in old formulas and referred to the art of building and creating in completely different areas, i.e. political and moral reality, and man himself. In this way, Freemasons created a situation of 'double concealment' by turning their guild background into their origin myth, which Reinhart Koselleck calls 'a myth about the source of the "highest" age'. ${ }^{13}$

Koselleck points out that the myth became particularly important during the Enlightenment, when a new goal emerged

${ }_{12}$ Ibidem, pp. 30-31.

${ }^{13}$ R. Koselleck, Critique and Crisis..., p. 73. 
for the Masonic organisations, which was "to "polish" the crude human being. ${ }^{14}$ At that time, the afore-mentioned game between the secret organisation and its overt politics became evident. In order to achieve their goal, which was to build a new society and a new man, members of Masonic lodges sought to influence the political reality, though they could not do so directly due to the need for secrecy. Their new programme, which concerned primarily moral issues, was most helpful in this respect. Thanks to the historical situation, the programme allowed them to break into the sphere of openness and participate in the creation of a new political reality. It was most important for them to separate politics and morality and to recognise the superiority of moral law. The first point of the Constitution of the Freemasons stated that 'a Mason is obliged by his tenure to obey the moral law'. ${ }^{15}$

The concept of sovereignty, which was developed in Europe along with the idea of a modern state since the $17^{\text {th }}$ century, led to the absolutization of power, an important element of which was monopolised forms of participation, i.e. people could engage in the sphere of politics only by the will of a ruler. This triggered the reaction of new bourgeois elites, particularly in France, who, led by a sense of political exclusion, began to strive to limit absolute power by exerting various pressures on power, including financial dependence, assemblies or pressures on the royal council. As Koselleck notes:

In this interrelation between finance capital - which in society's hands was at the same time a credit balance - and the financial indebtedness of the State, which quite immorally used its political power to conceal or strike out its debts, lay one of the strongest social impulses for the dialectic of morality and politics. ${ }^{16}$

\footnotetext{
${ }_{14}$ Ibidem, p. 71.

${ }^{15}$ As Joseph Uriot stated in the work entitled Le secret de Franc-Maçons mis en evidence (1744), Freemasons were interested in architecture, eloquence, poetry, painting, philosophy, morality, history and subtle subordination to the wisdom of pleasure. Politics and religion were rejected as too controversial. See ibidem.

${ }^{16}$ Ibidem, p. 64.
} 
In such an atmosphere, attempts were made by Freemasonry to create an alternative institutional reality, a new society. Secret organisations were also connected at this level with enlightened scholars and intellectuals who formed an emerging new social layer. This coalition, however, represented a broader social spectrum. According to Koselleck, it was formed primarily by: noblemen, who enjoyed inherited prestige but had no political influence; the bourgeois, who had financial resources, but were stigmatised as homines novi; and financiers, who played a significant spiritual role, but were helpless in the face of state power. These new groups created a new social space through meetings in non-political places, such stock exchanges, shopping centres, academies, clubs and lounges. Their common fate led to the formation of an unofficial non-state level of interests, i.e. a space of society (société) that offered each of the excluded groups its own place. It was this new society that created new social organisations or redefined their functions, as was the case with Freemasonry.

According to Koselleck, this helped the Masonic organisation develop a new social content of its mystery, which contained the slogans of equality of all social strata, freedom from the state, as well as the internal rule of law and legislation. This gave the lodges a political character and the mystery served as a protection of their programme. This also meant that an internal non-state spiritual space' was developed in the form of a new quasi-religion within the emerging bourgeois society. The rapidly growing public sphere and the resulting different forms of criticism made it possible to overcome religious tensions by means other than those previously used by the state. As Koselleck writes, 'masonry was the social realisation of bourgeois moral doctrine. ${ }^{17}$

It was particularly in France that this moral, rather than political, character of secret institutions gained in significance through opposition to the increasingly immoral state power. Thus, the institutionalisation of society took place in a secret way, but

${ }^{17}$ Ibidem, p. 74. 
the influence of these institutions on power was not yet direct. According to Koselleck, the mystery protected by the Masons covers 'the political reverse of the Enlightenment'. ${ }^{18}$ As in the case of Odysseus, social involvement in politics, which can be considered a form of 'garrulity', provoked the authorities to take 'dangerous steps' and reach for violence: they imposed a ban on the lodge in Paris and introduced censorship. Koselleck describes historical events to show that through such repression the State compelled it [the new leading social stratum] to re-emigrate into the underground privacy of its origin'. ${ }^{19}$

In this way, through its activity in the public sphere, Freemasonry remained a secret organisation, yet it supported the emergence of a new society and led to its involvement in the political sphere in the process of revolution.

If we agree with philosophers that it is also in politics that what is concealed precedes and determines that what is disclosed - in this case, it precedes and conditions the emergence of new political forms and structures - it seems reasonable to say that entirely overt politics is impossible. What is overt is by its very nature connected with what has 'already been revealed', like an iceberg that hides a much larger implicit sphere. Furthermore, due to the close link between these two spheres, that what has been shaped in the sphere of closedness and in conflict with existing structures is extracted and disclosed, thereby changing the sphere of openedness and the existing political form, including the very form of power. In turn, new forms of resistance that are hidden in its shadow will adapt to this new form of power.

I, therefore, believe that a completely transparent and overt political sphere is impossible. If the demand for the transparency of politics is raised to the level of worship, as Ivan Krastev rightly points out, the idea of trust is undermined and transparency 
becomes an illusion. ${ }^{20}$ This does not mean, however, that we should give up the desire to reveal and disclose that what is concealed. I have tried to show that the very process of such disclosure is extremely important to change and renew the political sphere and to maintain civic involvement in politics. It is necessary to disclose political secrets, hidden actions and conspiracies to "clarify the situation' and heal politics itself, the very essence of which is transparency. If the sphere of secret actions is too strong and too much developed and if it exerts too much influence on the sphere of transparency, politics and politicians become corrupted. Niccolò Machiavelli was aware of this when he explored the issue of an organisation and the course of a political conspiracy using the example of the Pazzi conspiracy. According to him, conspiracies and plots corrupt the political sphere in a particular way:

Thus the prince of a city attacked by conspiracy, if not slain like the duke of Milan (which seldom happens), almost always attains to a greater degree of power, and very often has his good disposition perverted to evil. The proceedings of his enemies give him cause for fear; fear suggests the necessity of providing for his own safety, which involves the injury of others; and hence arise animosities, and not unfrequently his ruin. Thus these conspiracies quickly occasion the destruction of their contrivers, and, in time, inevitably injure their primary object. ${ }^{21}$

It must, therefore, be said that when overt politics is influenced by secret structures, the afore-mentioned game of appearances and simulations enters the sphere of politics. Maintaining the mystery requires cunningness, shrewdness and violence. If secrets are not disclosed for too long, they contribute to the creation of a new political system and can cause an epidemic of suspicion or fear, as was the case of Freemasonry which

\footnotetext{
${ }^{20}$ Cf. I. Krastev, Demokracja nieufnych... and Jacek Żakowski's interview with Ivan Krastev "Więcej tajemnicy. Iwan Krastew filozof polityki, o tym, jak nadmiar jawności niszczy zaufanie i szkodzi demokracji," Polityka, No. 6 (2944), 5-11 February 2014.

${ }^{21}$ N. Machiavelli, History of Florence and of the Affairs of Italy, Walter Dunne, New York - London 1901, http://www.freeclassicebooks.com/Nicolo\%20Machiavelli/History\%20Of\% 20Florence\%20And\%20Of\%20The\%20Affairs\%20Of\%20Italy.pdf, p. 512.
} 
continues to have a bad reputation in society. Politics, however, cannot do without this game of appearances. When considering the case of WikiLeaks, Slavoj Žižek, similarly to Koselleck, points to the mobilising nature of the process of revealing secrets, which aims at establishing new patterns of the functioning of power. ${ }^{22}$ However, he is convinced that the disclosure of everything does not form the basis for a new, proper political form. Politics largely depends on this game of appearances, without which there are no compromises or ideologically impossible arrangements that help to avoid catastrophes, such as wars. Therefore, while appreciating the political principle of overtness and transparency, I believe that we should remember about the disappearing techne politike, which involves diplomacy, tactfulness and the ability to use understatements and polite forms.

\section{Secret organisations and their overt politics}

In line with the concept of politics developed by ancient Greeks, the political sphere is identified with transparency and overtness. However, it has always been hiding secret actions, conspiracies and collusions. The emergence of the modern model of the state, along with the rationalisation of its structures, enabled the secret equivalents of authority to transform into organisations, i.e. institutions alternative to official organisations, established by law and having specific powers. Rather than talking about actual organisations, the author discusses the process whereby these secret, underground structures turn into organisations that influence the sphere of overt politics. She tries to show that this is a specific kind of game between what is explicit and public and what is concealed and secret. This game is constantly present in political activities, although we seldom realise it.

Keywords: public sphere, transparency, secrecy, mystery, simulation, secret organisations, Freemasonry.

${ }^{22}$ S. Žižek, 'Spisek kontrolowany', London Review of Books, as quoted in Forum, No. 4, 24-30 January 2011. 